\title{
Interleukin-10 Receptor Subunit Alpha
}

National Cancer Institute

\section{Source}

National Cancer Institute. Interleukin-10 Receptor Subunit Alpha. NCI Thesaurus. Code C107586.

Interleukin-10 receptor subunit alpha (578 aa, $\sim 63 \mathrm{kDa}$ ) is encoded by the human IL10RA gene. This protein plays a role in the regulation of immunosuppression. 